This is a self-archived - parallel published version of this article in the publication archive of the University of Vaasa. It might differ from the original.

\title{
International joint ventures research on Africa: A systematic literature review, propositions, and contextualization
}

Author(s): Oguji, Nnamdi; Degbey, William Y.; Owusu, Richard A.

Title: International joint ventures research on Africa: A systematic literature review, propositions, and contextualization

Year: $\quad 2021$

Version: Accepted manuscript

Copyright (C)2021 Wiley. This is the peer reviewed version of the following article: Oguji, N., Degbey, W. Y. \& Owusu, R. A. (2021). International joint ventures research on Africa: A systematic literature review, propositions, and contextualization., which has been published in final form at https://doi.org/10.1002/tie.21993. This article may be used for non-commercial purposes in accordance with Wiley Terms and Conditions for Use of Self-Archived Versions.

Please cite the original version:

Oguji, N., Degbey, W. Y. \& Owusu, R. A. (2021). International joint ventures research on Africa: A systematic literature review, propositions, and contextualization. Thunderbird International Business Review 63(1), 11-26. https://doi.org/10.1002/tie.21993 


\title{
IJVs Research on Africa: A Systematic Literature Review, Propositions, and Contextualization
}

\author{
By \\ Dr. Nnamdi Oguji \\ University of Vaasa, Finland \\ nnamdi.oguji@gmail.com \\ Dr. William Y. Degbey \\ Turku School of Economics, University of Turku, Finland \\ william.degbey@utu.fi \\ Dr. Richard A. Owusu \\ Linnaeus University \\ richard.owusu@lnu.se
}

\begin{abstract}
This study reviewed the research on international joint ventures (IJVs) in Africa up to 2017. The authors performed a systematic search of peer-reviewed good quality research using the $6 \mathrm{~W}$ procedure and ensuring the quality of the review by using the $5 \mathrm{Cs}$ quality criteria. The content analysis was focused on four research questions. A total of 22 relevant studies were found. Overall, only about one-third of the lead authors were affiliated with African universities. A majority of the studies were quantitative, and $78 \%$ of the studies were done for three countries: Ghana, Morocco, and Nigeria. There was either just one or no study on trust and conflict, partner selection, and human resource management $(\mathrm{HRM})$. At the contextual level, it seems that the most important factor influencing IJV strategy and success is institutions. We therefore suggest a greater use of
\end{abstract}


institutional theory. Finally, we present a summary conceptual framework and four propositions to guide future research.

\section{Introduction}

The increasing foreign direct investment (FDI) inflows into several African countries are the result of market reforms and economic liberalization policies implemented over the past three decades (Bartels, Napolitano, \& Tissi, 2014; Dadzie, Owusu, Amoako, \& Aklamanu, 2017; Degbey \& Ellis, 2017; World Bank, 2011, 2012). While the total value of acquisitions in Africa is twice that of the previous decade (UNCTAD, 2015), the use of the greenfield alternative entry mode has also risen because of the rapidly improving formal institutions in many African countries (Chen, Cui, Li, \& Rolfe, 2017). Despite these trends, some African governments still have several restrictive laws on mergers and acquisitions (M\&A) (Oguji \& Owusu, 2017a), which, in addition to local content legislation (Vaaland, Soneye, \& Owusu, 2012), host government suasion (Bartels et al., 2002), and challenges in valuating targets and accessing necessary financing, make international joint ventures a viable strategy for firms seeking market entry into Africa.

International joint ventures (IJVs) or partially owned greenfields are a prevalent strategy used by foreign firms to gain market entry into Africa (Boateng, 2004). In a greenfield organization, a foreign firm shares the ownership stake with a local partner (Chen, 2008), and the equity share serves as a means to exercise ownership and control over the joint venture (Bowe, Golesorkhi, \& Yamin, 2014). Through IJVs, both partners leverage their capabilities, learn and develop new expertise, and achieve enhanced profitability and synergies (Beamish \& Berdrow, 2003; Ado, Su, \& Wanjiru, 2017). 
A literature review of existing studies on IJVs suggests that existing research is dominated by the advanced economies in Europe and North America, as well as the recently emerging economies of Asia and Latin America. The scant research on Africa is the reason for the recent call for studies focusing on IJVs in Africa (Oguji \& Owusu, 2017b), as there exists a need to discuss the importance of the African context and the ways it can shape IJV research in international business. This paper answers this call by conducting a systematic literature review of existing studies on Africa. Our objective is to examine the extant IJV research on Africa to understand what we know thus far, whether the African context is unique, and how we can advance future IJV research in Africa. We approached our objective through four research questions:

RQ1: What are the characteristics of IJV research on Africa?

RQ2: What do we know about IJVs in Africa?

RQ3: How have these studies affected the conceptualization of IJVs?

RQ4: What might be some promising avenues for future research?

Our literature review and the answers to these research questions have enabled us to discuss the IJV context in Africa, contrast it with those of developed economies, shed light on its uniqueness, and suggest several potential IJV themes in the context of Africa. We believe that examining the African context will contribute to contextualized explanations in international business research, enrich theory, and provide contextual aspects that have so far been unexplored (e.g., Meyer \& Peng, 2005; Van de Ven \& Jing, 2011; Welch, Piekkari, Plakoyiannaki, \& Paavilainen-Mäntymäki, 2011). We approach this paper as follows: The first section focuses on the procedure of the systematic literature review, which involves a search and thematic analysis of the literature up to 2017. The second section discusses the characteristics of the researchers and their publications. 
The third section discusses the themes and current knowledge about IJVs in Africa. Fourth, we discuss the context-specific contributions of these studies and compare them with the contributions of research on advanced economies. Based on the contextualized explanation, we formulate propositions. Finally we recommend a future research agenda for IJVs in Africa.

\section{Literature Review Design and Protocol}

We conducted a systematic literature review to uncover the importance of the African context and its role in shaping IJV research. A systematic literature review enables us to critically examine IJV issues in the African context by integrating existing studies, summarizing prior IJV contributions, locating knowledge gaps, and developing new theoretical frameworks that will contribute to the international business literature (e.g., Marabelli \& Newell, 2014; Xie, Reddy, \& Liang, 2017).

Our literature review followed the 6Ws literature review design (Callahan, 2014; Xie et al., 2017) and employed the 5Cs as quality criteria (Callahan, 2014). The 6Ws protocol is comprised of who (who conducted the search for data), when (when the data were collected), where (where the data were collected), wherein (how the data were collected), what (what was kept and what was discarded), and why (why the selection criteria were used) (Callahan, 2014; Xie et al., 2017).

Who (who searched for the data?): The search was conducted independently by all authors to ensure the consistency and validity of the search process.

When (when were the data collected?): The lead author conducted the initial search in 2016. A later search was conducted by all authors in 2017 after the 2017 Thunderbird call for papers on IJV research in Africa.

Where (where were the data collected?): The search was focused on peer-reviewed journal publications up to 2017, without restrictions on the initial year of analysis. Books, and conference 
proceedings were not considered because peer-reviewed articles have the most impact in scholarly research (e.g., Martineau \& Pastoriza, 2016; Podsakoff, MacKenzie, Bachrach, \& Podsakoff, 2005).

Wherein (how were the data collected?): The literature search was done using SCOPUS, Business Source Premier, and PROQUEST in systematic steps. First, the authors searched SCOPUS for specific keywords-“Joint Ventures" AND "Africa." A total of 121 articles were found. The titles of these 121 articles were copied and uploaded to an Excel sheet. A second keyword search for "Joint Ventures" and the names of each country in Africa (e.g., Nigeria, Ghana, South Africa, Cameroon, Kenya, Egypt, and Morocco) was done. The titles of all the articles found were also copied to an Excel sheet. After eliminating duplicates, a total of 140 unique articles were left. The same search process was repeated in Business Source Premier and PROQUEST. Three new articles were found in Business Source Premier, and the remaining articles were duplicates of articles already identified in SCOPUS. Thus, in all, 143 unique articles were found. In selecting suitable papers, the authors checked for articles that focused on issues within the scope of IJV research, as shown in Figure 1. 


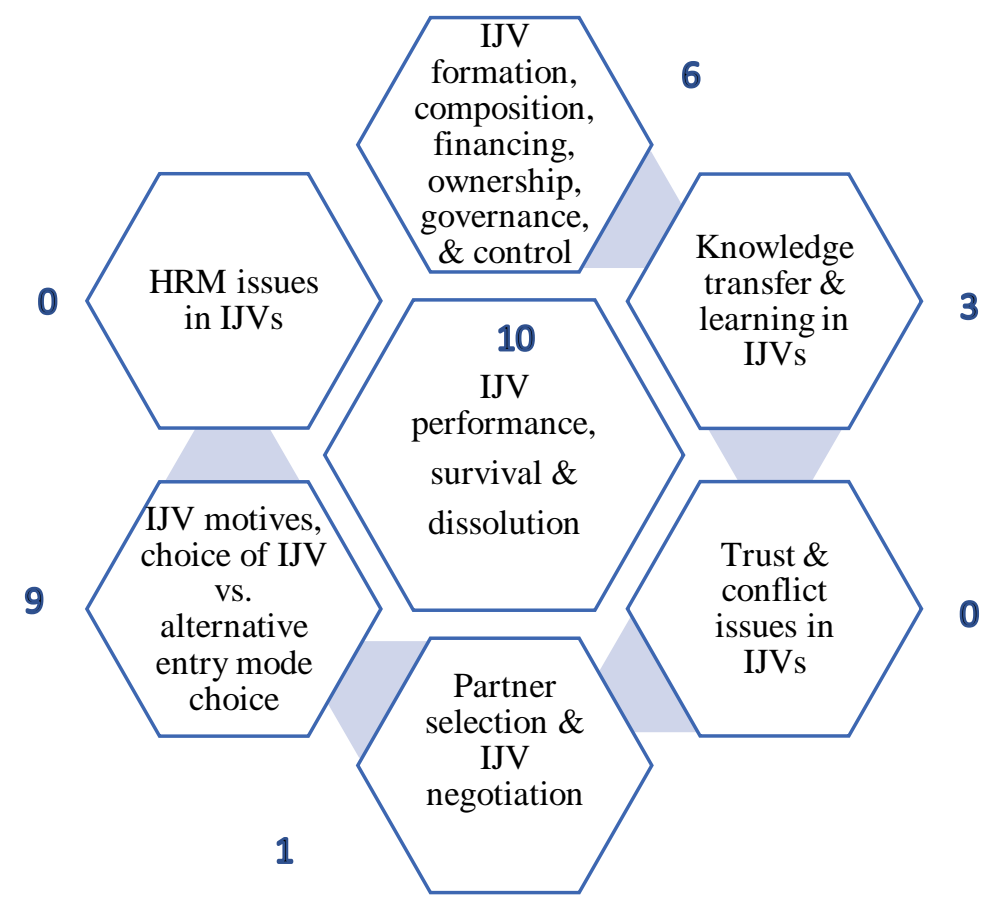

Figure 1: Scope of IJV research

The authors read each of the articles, and a total of 22 relevant articles were found. Table 1 shows the relevant articles and the respective keywords and databases.

Table 1: Keyword and Search Results

\begin{tabular}{|l|l|l|r|}
\hline Keyword & $\begin{array}{l}\text { Selected studies } \\
\text { (Scopus) }\end{array}$ & $\begin{array}{l}\text { Selected studies } \\
\text { (Business Source Premier) }\end{array}$ & $\begin{array}{l}\text { Selected studies } \\
\text { (PROQUEST) }\end{array}$ \\
\hline $\begin{array}{l}\text { International Joint Venture } \\
\text { AND Africa }\end{array}$ & 18 & 3 & 0 \\
\hline $\begin{array}{l}\text { International Joint Venture } \\
\text { AND "African Countries" }\end{array}$ & 1 & 0 & 0 \\
\hline
\end{tabular}

What (what was kept and discarded): After the search process, 22 relevant articles were selected.

Other articles that did not focus on IJV research as identified in Figure 1 were eliminated.

Why (why the selection criteria used): The authors are experienced IB researchers. However, to avoid bias, we sent Figure 1 to three additional researchers with more than 15 individual publications focusing on issues in IJVs. They confirmed that our figure is a good representation of the scope of IJV research, thus confirming our selection criteria. 
The quality of the systematic literature review was ensured by using the $5 \mathrm{C}$ criteria (concise, clear, critical, convincing, and contributive). The authors sought to ensure that the argumentation of the extant studies was concise and clear. Furthermore, we ensured that our review was critical and convincing by developing a critical review procedure comprised of eight analytical points (for a similar procedure, see Bozic, 2017; Creswell, 2013). The eight analytical points were (1) bibliographic details, (2) focus area of the paper within the IJV research paradigm, (3) theory used, (4) key findings, (5) methodology, (6) geographical location of the study (parent vs. home country), (7) research context, and (8) theoretical and practical contribution and reported limitations. Finally, we ensured the contribution of our systematic literature review by contextualizing the IJV research within the African context and contrasting it with studies involving other developed economies. In our contextualization, we were mindful not to generalize and to oversimplify the African context. African countries are classified as developing economies because of their low incomes, lack of well-established developed market institutions to coordinate economic activities, and reliance on informal institutional networks (United Nations, 2014). The development path and pace of institutional change are different for each country; consequently, we allowed for intra-country variations (Kostova \& Hult, 2016). Our contextualization was not limited to institutions but allowed for broader contextualization: for example, learning and knowledge transfer (e.g., Meyer, 2007), cultural (e.g., Peterson, 2016), and industry contexts (e.g., Jacobides, 2005). 


\section{What are the Characteristics of IJV Research in Africa?}

\subsection{Bibliographic details}

Table 2 shows the authors, years of publication, journals of publication, Scimagojr Journal Rank (SJR), and SCOPUS Citation Index of Article (CIA). We created a correlation matrix for the yearly citation index of the article, the year of publication, and the SJR. We expected, as suggested in the literature (e.g., Abramo et al., 2014), that the higher the SJR of the publication, the higher would be the citation index of the article because authors prefer to reference publications in highly ranked rather than low-ranked journals. In addition, we expected that the older the publication year of the article, the higher the citation index would be. Overall, the main motivation of the authors was to understand how influential these articles have been in mainstream IJV research. There was a moderate positive correlation between the yearly citation index of the article and the SJR (Corr $=0.49, \mathrm{n}=22, \mathrm{p}<0.05)$. Similarly, we found a moderate negative correlation between the year of publication and the total citation index of the article (Corr $=0.51, \mathrm{n}=22, \mathrm{p}<0.05)$. The correlation showed a moderate affirmation of our expectations (See Figures 2-3 and Table 3 for graphs and correlation matrix, respectively).

Table 2: Journal Publications and Bibliographic Details

\begin{tabular}{|l|l|l|l|}
\hline Authors & Journal Name & SJR & CIA \\
\hline Caroline \& Brian (2001)* & International Journal of Tourism Research & 1.144 & \\
\hline Boateng \& Glaister (2002) & International Business Review & 1.193 & 42 \\
\hline Boateng \& Glaister (2003)* & Management International Review & 0.844 & \\
\hline Carrillo (1996) & Construction Management and Economics & 0.89 & 21 \\
\hline Ngowi (2007) & Building and Environment & 2.015 & 18 \\
\hline Boateng (2004) & International Journal of Social Economics & 0.225 & 17 \\
\hline Luiz \& Charalambous (2009) & International Business Review & 1.193 & 14 \\
\hline Acquaah (2009) & Journal of International Management & 1.849 & 11 \\
\hline $\begin{array}{l}\text { Famakin, Aje \& Ogunsemi } \\
(2012)\end{array}$ & Journal of Fin. Mgt. of Property \& Const. & 0.185 & 8 \\
\hline Hearn (2015) & Journal of World Business & 1.974 & 5 \\
\hline
\end{tabular}




\begin{tabular}{|l|l|l|l|}
\hline Bartels et al. (2002) & Journal of African Business & 0.45 & 4 \\
\hline Argente-Linares, et al. (2013) & Review of Managerial Science & 0.504 & 4 \\
\hline Dadzie et al. (2014) & Journal of Transnational Management & 0.211 & 2 \\
\hline Banai \& Akande (2005) & Journal of African Business & 0.45 & 1 \\
\hline Boateng et al. (2002) * & International Journal of Business Studies & & \\
\hline Ado, Su, \& Wanjiru (2017) & Journal of International Management & 1.849 & 1 \\
\hline Gómez-Miranda et al. (2015) & Personnel Review & 0.589 & 1 \\
\hline Foster-Mcgregor et al. (2015) & Journal of International Development & 0.477 & 1 \\
\hline Odediran \& Windapo (2017) & Journal of Managt. in Engineering - ASCE & 1.061 & 0 \\
\hline Argente-Linares et al. (2013) & South African Journal of Bus. Management & 0.159 & 0 \\
\hline Dadzie et al. (2017) & Thunderbird International Bus. Review & 0.925 & 0 \\
\hline Kivrak et al. (2014) & Canadian Journal of Civil Engineering & 0.388 & 0 \\
\hline
\end{tabular}
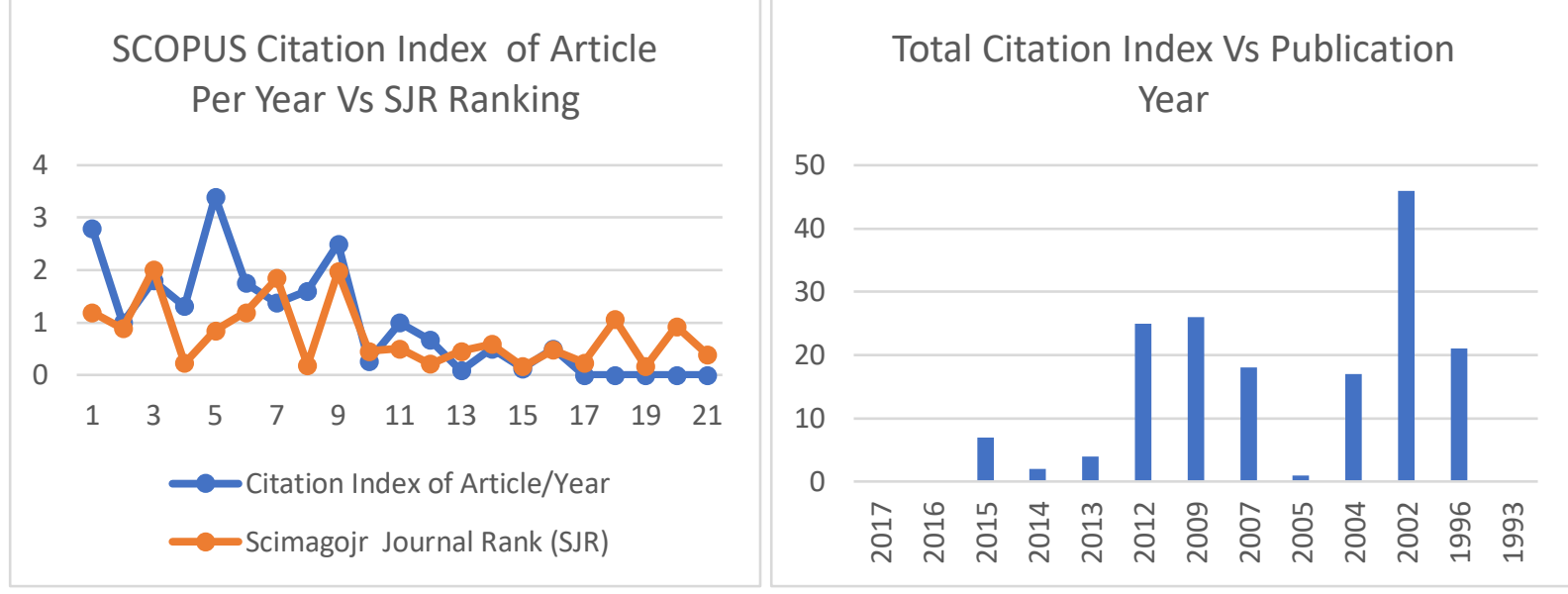

Figure 2: Graph of CIA/year vs. SJR

Figure 3: Graph of CIA vs. Year of Publication.

Table 3: Correlation Matrix: CIA per Year vs. SJR and CIA vs. Year of Publication

\begin{tabular}{|l|l|l|l|l|l|}
\hline $\begin{array}{l}\text { Spearman } \\
\text { Rank } \\
\text { Correlations }\end{array}$ & CIA/Year & (SJR) & $\begin{array}{l}\text { Spearman } \\
\text { Rank } \\
\text { Correlations }\end{array}$ & CIA of Article & Year \\
\hline CIA/Year & 1.0000 & 0,4871 & ClA of Article & 1.0000 & $-0,5082$ \\
\hline (SJR) & p-value $\mathbf{= 0 . 0 2 5 1}$ & 1,0000 & Year & p-value $=\mathbf{0 . 0 1 8 6}$ & 1,0000 \\
\hline
\end{tabular}

Two-thirds $(67 \%)$ of the lead authors were affiliated with foreign universities, while one-third (33\%) were affiliated with universities located in Africa. Universities in the United Kingdom had the highest number of studies dealing with IJV issues in Africa (32\%), followed by Spain (14\%), South Africa (9\%), and the United States and Ghana (9\% each). Universities in Australia, Turkey, Botswana, Canada, Austria, and Nigeria had only one publication (5\%). Table 4 shows the authors' 
affiliations and the locations of the universities. Overall, authors affiliated with institutions outside Africa appeared to research IJV issues in Africa more than authors affiliated with institutions in Africa. This could be attributed to the challenges faced by African universities in producing international business (IB) scholars (Ellis \& Zhan, 2011; Svensson, Tronvoll, \& Slatten, 2008). There is thus a need for local IB researchers and business schools in Africa to start researching IJV as well as IB themes in Africa.

Table 4: Authors' Affiliations and Locations

\begin{tabular}{|l|l|r|l|}
\hline Lead Author Name & Lead Author Affiliation & \# Articles & Location \\
\hline Boateng, Agyenim & Leeds Metropolitan University UK & 4 & UK \\
\hline Carrillo, Patricia & The Loughborough University of Technology & 1 & UK \\
\hline Bartels, Frank L. & James Cook University, Townsville, Australia & 1 & Australia \\
\hline Banai, Moshe & Zicklin School of Business, New York, US & 1 & US \\
\hline Famakin, I.O & Federal University of Technology, Akure & 1 & Nigeria \\
\hline Ashley, Caroline & Overseas Development Institute, London & 1 & UK \\
\hline Ado, Abdoulkadre & University of Ottawa & 1 & Canada \\
\hline Hearn, Bruce & University of Sussex & 1 & UK \\
\hline Acquaah, Moses & University of North Carolina, Greensboro & 1 & US \\
\hline Kivrak, Serkan & Anadolu University, Eskisehir & 1 & Turkey \\
\hline Dadzie, Samuel A. & Ghana Institute of Management \& Public Adm. & 2 & Ghana \\
\hline Argente-Linares, E. & University of Granada & 2 & Spain \\
\hline Ngowi, A.B. & University of Botswana & 1 & Botswana \\
\hline Luiz, John Manuel & University of the Witwatersrand, Johannesburg & 1 & South Africa \\
\hline Foster-Mcgregor, N. & Vienna Institute for International Econ. Studies & 1 & Austria \\
\hline Gómez-Miranda, E. & University of Granada, Granada & 1 & Spain \\
\hline Odediran, Sunday J. & University of Cape Town & 1 & South Africa \\
\hline
\end{tabular}

\subsection{Methodology}

The predominant methods in the studies in the sample were quantitative-18 $(77 \%)$ out of 22 articles (see Table 5). The quantitative methods included statistical analyses employing secondary data (collected from available databases, e.g., Foster-Mcgregor et al., 2015; Hearn, 2015) and primary data (collected through surveys). One article used a case study methodology, where respondents were surveyed using structured questionnaires (Famakin, Aje, \& Ogunsemi, 2012). 
Four articles (18\%) employed qualitative methods, two of which involved multiple case studies.

Only one article used a mixed method design (Odediran \& Windapo, 2017).

Table 5: Methodology and Research Designs: IJVs Literature in Africa

\begin{tabular}{|l|l|l|l|l|l|}
\hline Authors & Methodology & Sample & Response & Data analysis & Dataset \\
\hline Ado et al. (2017) & CS (Qualitative) & 29 & N/A & Content analysis & Primary \\
\hline Dadzie et al. (2017) & Quantitative & 115 & $30 \%$ & Binomial logistic & Primary \\
\hline Odediran \& Windapo (2017) & Mixed-methods & 76 & $33.5 \%$ & Mixed method & Primary \\
\hline Hearn (2015) & Quantitative & 202 & N/A & Logistic regression & Secondary \\
\hline Foster-Mcgregor et al. (2015) & Quantitative & 5029 & N/A & Ordinary least squares & Secondary \\
\hline Gómez-Miranda et al. (2015) & Quantitative & 76 & $38.10 \%$ & Multivariate analysis & Primary \\
\hline Dadzie et al. (2014) & Quantitative & 75 & $32.6 \%$ & Ordinary least squares & Primary \\
\hline Kivrak et al. (2014) & CS (Qualitative) & 1 & N/A & Content analysis & Primary \\
\hline Argente-Linares et al. (2013a) & Quantitative & 210 & $32.50 \%$ & OLR & Primary \\
\hline Argente-Linares et al. (2013b) & Quantitative & 76 & $32.50 \%$ & Linear regression & Primary \\
\hline $\begin{array}{l}\text { Famakin, Aje \& Ogunsemi } \\
\text { (2012) }\end{array}$ & CS (Quantitative) & 21 & $60 \%$ & & \\
\hline Acquaah (2009) & Quantitative & 76 & $76 \%$ & Oactor analysis & Primary \\
\hline Luiz \& Charalambous (2009) & Quantitative & 20 & $24 \%$ & Distribution-fitting & Primary \\
\hline Ngowi (2007) & Quantitative & 28 & $100 \%$ & Descriptive Statistics & Primary \\
\hline Banai \& Akande (2005) & Quantitative & 103 & $57 \%$ & Friedman's 2-ANOVA & Primary \\
\hline Boateng (2004) & Quantitative & 41 & $45.60 \%$ & T-test \&ANOVA & Primary \\
\hline Boateng \& Glaister (2003) & Quantitative & 41 & $45.60 \%$ & Factor analysis, F-test & Primary \\
\hline Bartels et al. (2002) & Quantitative & 45 & $76.30 \%$ & Descriptive Statistics & Primary \\
\hline Boateng et al. (2002) & Quantitative & 57 & $35.60 \%$ & Paired t-test & Primary \\
\hline Boateng \& Glaister (2002) & Quantitative & 57 & $35.60 \%$ & Multiple regression & Primary \\
\hline Ashley \& Jones (2001) & Qualitative & 11 & N/A & Interpretive & Primary \\
\hline Carrillo (1996) & CS (Qualitative) & 4 & N/A & Interpretive & Primary \\
\hline
\end{tabular}

The qualitative studies used large sample sizes ranging from 4 to 29. Kivrak, Arslan, Tuncan, and Birgonul (2014) had a single case study with multiple respondents (12). Similarly, the sample sizes for the quantitative studies were large, ranging from 21 to 5,029 firms. Excluding Foster-Mcgregor et al. (2015), with an outlier sample size of more than 5,000 firms, the average sample size was 81 respondents. The average response rate for the quantitative studies (excluding an outlier of 100\% in Ngowi, 2007) was $44.482 \%$ ( $\mathrm{SD}=16.7)$. This rate is close to the average response rate of 44.71 $(\mathrm{SD}=22.80)$ found in a review of the leading marketing and international business journals published between 1990 and 2013 and higher than the average response rates in Brazil, Ireland, Spain, Hong Kong, and Australia (Mellahi \& Harris, 2016). In the same study, based on the respondents' country of origin, Africa had the highest mean response rate $($ mean $=57.70)$. This 
suggests that IJV research themes in the African context and IB research in general do not suffer from data/respondent unavailability, as has been reported in other disciplines (e.g., Kolk \& Lenfant, 2010). Consequently, the reason for the under-representation of research on these themes could be research interest, availability of research funding, or the strategic orientation of business schools in Africa.

The qualitative studies employed mainly two analytical techniques: content analysis (e.g., Ado et al., 2017; Kivrak et al., 2014; Wanjiru, 2017) and interpretive procedures (e.g., Ashley \& Jones, 2001; Carrillo, 1996); however, a clear description of the approach was missing in most of the studies. We believe that there is room for improvement in establishing qualitative research designs and protocols (e.g., Easton, 2010; Healy \& Perry, 2000; Miles \& Huberman, 1984; Sinkovics, Penz, \& Ghauri, 2008; Sobh \& Perry, 2006; Welch et al., 2011) and explicitly describing the methods and processes used. Moreover, to improve the contextualization of African IJV themes and to contribute to IB theory, researchers must go beyond the traditional IB research methods and employ methods that allow for a better contextualization of African IJV themes (e.g., critical realism, mixed methods, and longitudinal studies).

\subsection{Countries of Focus}

The host countries of the IJV foreign partners were in Asia, Europe, North America and Southern Africa. The respondents varied from IJV managers, CEOs, and IJV staff members to parent multinationals (MNE) and IJV stakeholders (government ministries, IJV managers, etc.) (see Table 6 for an overview). Single host country IJVs accounted for 59\% (13) of the total studies (22), of 
which $22 \%$ (5) involved both single home countries and single host countries. Multiple host and home countries accounted for $35 \%$ (8) of the studies.

Table 6: Countries of Studies and Respondents

\begin{tabular}{|l|l|l|l|}
\hline Authors & Parent Country & Host Countries & Respondent \\
\hline Ado et al. (2017) & China & 10 SSA countries & IJV stakeholders \\
\hline Dadzie et al. (2017) & 23 foreign countries & Ghana & IJV managers \\
\hline Odediran \& Windapo (2017) & South Africa & 19 African countries & MNE parent firm \\
\hline Hearn (2015) & Eur, MEast, US, Af, \& S Asia & 22 African countries & N/A \\
\hline Foster-Mcgregor et al. (2015) & Not specified & 19 SSA countries & N/A \\
\hline Gómez-Miranda et al. (2015) & Spain & Morocco & IJV CEO \\
\hline Dadzie et al. (2014) & 19 foreign countries & Ghana & IJV managers \\
\hline Kivrak et al. (2014) & South Korea & Libya & IJV staff \\
\hline Argente-Linares et al. (2013a) & Spain & Morocco & IJV CEO \\
\hline Argente-Linares et al. (2013b) & Spain & Morocco & IJV CEO \\
\hline $\begin{array}{l}\text { Famakin, Aje \& Ogunsemi } \\
\text { (2012) }\end{array}$ & Not specified & Nigeria & Managers and staff \\
\hline Acquaah (2009) & EM \& developed con & Ghana & IJV CEO \\
\hline Luiz \& Charalambous (2009) & South Africa & 7 SSA countries & MNE parent firm \\
\hline Ngowi (2007) & Kuwait, SA, \& Botswana & Botswana & IJV CEO \\
\hline Banai \& Akande (2005) & US & South Africa & IJV managers \\
\hline Boateng (2004) & W Europe, NA, \& Asia & Ghana & IJV managers \\
\hline Boateng \& Glaister (2003) & W Europe, NA, \& Asia & Ghana & IJV managers \\
\hline Bartels et al. (2002) & UK & Ghana \& Côte D'Ivoire & MNE parent firm \\
\hline Boateng et al. (2002) & W Europe, NA, \& Asia & Ghana \& Nigeria & IJV top managers \\
\hline Boateng \& Glaister (2002) & W Europe, NA, \& Asia & Ghana \& Nigeria & IJV managers \\
\hline Ashley \& Jones (2001) & Foreign \& local firms & Namibia & Not specified \\
\hline Carrillo (1996) & UK & $\begin{array}{l}\text { Egypt, Lesotho, \& } \\
\text { Nigeria }\end{array}$ & MNE parent firm \\
\hline
\end{tabular}

Ghana, Morocco, and Nigeria received or were included in $78 \%$ (18) of the total studies (22). The use of multiple and single home and host countries has theoretical implications. First, the home country of the foreign partner may have an effect on its chosen IJV motives, strategies, formation, control mechanisms, and performance. A similar argument exists in a review of the establishment mode choice literature (e.g., Hennart \& Slangen, 2007). The lumping of countries into emerging markets and developed and industrialized nations may bias empirical findings because strategies are host country-specific because of the unique institutional development of each country. Although similarities and generalizations are possible, unique host country and host country effects should be controlled before empirical generalization. In line with Hennart \& Slagen (2007), we 
recommend that future IJV studies in Africa focus on single foreign parent and host country IJVs if researchers do not want to control for home and host country effects. Africa is a large continent with more than 50 countries with different cultures and levels of institutional development and business cultures. Thus, research findings involving multiple home and/or host countries in Africa can be generalized only after controlling for both home and host country-level factors. Consequently, we recommend that researchers interested in the effect of the specific nationality of a foreign partner on IJVs should include varying datasets of nationalities of the foreign partners in a single host country and vice versa (Hennart \& Slangen, 2007). In this way, empirical findings could be contextualized and generalized for the African context.

\subsection{Theories explored}

Most of the studies used literature synthesis without specific or focused IB theories (See Table 7) in their theoretical analyses. This could be a result of the nature of the themes explored. Eight studies (36\%) used IB theories, such as social capital theory (Ado et al., 2017), the OLI paradigm (Dadzie et al., 2014; Dadzie et al., 2017), institutional theory (Hearn, 2015; Luiz \& Charalambous, 2009), resource dependency and structural contingency theory (Hearn, 2015), organizational culture and national culture theories (Gómez-Miranda et al., 2015; Kivrak et al., 2014), and the resource-based view and Porter's competitive strategy (Acquaah, 2009).

Table 7: Authors and Theories Applied

\begin{tabular}{|l|l|}
\hline Authors & Theories \\
\hline Ado et al. (2017) & Social capital theory \\
\hline Dadzie et al. (2017) & OLI paradigm \\
\hline Odediran \& Windapo (2017) & Literature synthesis \\
\hline Hearn (2015) & Institutional theory, resource dependency, \& structural contingency theory \\
\hline Foster-Mcgregor et al. (2015) & Literature synthesis \\
\hline Gómez-Miranda et al. (2015) & Theory of organizational culture \\
\hline Dadzie et al. (2014) & OLI paradigm \\
\hline Kivrak et al. (2014) & Hofstede's \& Hall's cultural dimensions theories \\
\hline Argente-Linares et al. (2013a) & Literature synthesis \\
\hline Argente-Linares et al. (2013b) & Literature synthesis \\
\hline
\end{tabular}




\begin{tabular}{|l|l|}
\hline Famakin, Aje \& Ogunsemi, (2012) & Literature synthesis \\
\hline Acquaah (2009) & Resource-based view \& competitive strategy literature \\
\hline Luiz \& Charalambous (2009) & Institutional environment \\
\hline Ngowi (2007) & Literature synthesis \\
\hline Banai \& Akande (2005) & Literature synthesis \\
\hline Boateng (2004) & Literature synthesis \\
\hline Boateng \& Glaister (2003) & Literature synthesis \\
\hline Bartels et al. (2002) & Literature synthesis \\
\hline Boateng et al. (2002) & Literature synthesis \\
\hline Boateng \& Glaister (2002) & Literature synthesis \\
\hline Ashley \& Jones (2001) & Literature synthesis \\
\hline
\end{tabular}

Despite their theoretical insights and contributions, IJV scholars interested in African IJV research themes could uncover additional contextual issues using network theories, the institution-based view of international business, social exchange theory, and the theories of corruption. In Section 5, we discuss the contributions of these theories to the development of theory and the contextualization of IJV themes. 
Table 8: Summary of Extant IJV Research in Africa and Empirical Findings

\begin{tabular}{|c|c|}
\hline Authors & Summary of Findings \\
\hline Carrillo (1996) & $\begin{array}{l}\text { - Difficulties experienced in transferring technology: Lack of local tunneling and management expertise in project planning, } \\
\text { project resource management, and project financing. } \\
\text { - Mechanisms used to transfer technology: Training by expatriates and staff; visiting manufacturing facilities in the HQ for } \\
\text { training, teamwork, and learning on the job (Egypt); socialization during out-of-work-hours to eliminate hierarchical } \\
\text { organization structure and the feeling of us vs. them (Lesotho) }\end{array}$ \\
\hline Ashley \& Jones (2001) & $\begin{array}{l}\text { - Critical factors that influence IJV success in the tourism sector include committed individuals, company philosophy, } \\
\text { facilitation, trust, time, local institutions, national policy context, and tourism market trends. }\end{array}$ \\
\hline Bartels et al. (2002) & $\begin{array}{l}\text { - Motives of IJVs: Market access and government suasion are more critical for IJVs between firms from developed countries } \\
\text { in the developing countries of Ghana and Côte D'Ivoire. } \\
\text { - IJV control mechanism is based on majority equity ownership and the control of functional operations and technology } \\
\text { management. }\end{array}$ \\
\hline $\begin{array}{l}\text { Boateng \& Glaister } \\
(2002)\end{array}$ & $\begin{array}{l}\text { - Determinants of performance include partner capabilities, congruity of motives, goals, and availability of capital. } \\
\text { - Level of control has a negative impact on IJV performance. } \\
\text { - IJVs with a private sector host partner perform better than IJVs with a government host partner. }\end{array}$ \\
\hline Boateng et al. (2002) & $\begin{array}{l}\text { - IJVs are financed by equity contributions from the partners. } \\
\text { - The partners rely on borrowing and retained profits to finance future growth. } \\
\text { - The amount of initial capital required for an IJV is related to host partner's choice of organization type (private vs. } \\
\text { public). }\end{array}$ \\
\hline $\begin{array}{l}\text { Boateng \& Glaister } \\
(2003)\end{array}$ & $\begin{array}{l}\text { - Overcoming regulatory restrictions, cost-sharing, and facilitating international expansion is the primary motivation for } \\
\text { IJVs in Ghana. } \\
\text { - The importance of motives varies with the sector of IJV activity, to a moderate extent the ownership level, and to a weak } \\
\text { extent the partnership type or nationality of the foreign partner. }\end{array}$ \\
\hline Boateng (2004) & $\begin{array}{l}\text { - Foreign JV partners in Ghana utilize more debt than the host partners because foreign investors gain greater flexibility in } \\
\text { repatriating funds aimed at averting unfavorable tax law barriers on the repatriation of dividends in Ghana. }\end{array}$ \\
\hline $\begin{array}{l}\text { Banai \& Akande } \\
(2005)\end{array}$ & $\begin{array}{l}\text { - South African managers enter IJVs with US parent companies to obtain financial and technological resources. } \\
\text { - Equal ownership is preferable in US-South African IJVs. }\end{array}$ \\
\hline Ngowi (2007) & $\begin{array}{l}\text { - IJV partner selection criteria are: resource complementarities, prior alliance experience and reputation, and firms with } \\
\text { similar statuses (complementary capabilities and compatible operating systems and practices). }\end{array}$ \\
\hline $\begin{array}{l}\text { Luiz \& Charalambous } \\
(2009)\end{array}$ & $\begin{array}{l}\text { - Knowledge of local culture, local relationships and networks are vital to achieving success in FDIs in the financial service } \\
\text { industry in Sub Saharan African (SSA) markets. }\end{array}$ \\
\hline Acquaah (2009) & $\begin{array}{l}\text { - IJVs with partners from emerging economies are more likely to pursue an efficiency-oriented business strategy. } \\
\text { - IJVs with partners from advanced economies are more likely to pursue a market effectiveness-oriented strategy. } \\
\text { - Emerging economy IJVs implementing an efficiency-oriented strategy of cost leadership outperform those with partners } \\
\text { from advanced economies implementing the same strategy, and vice versa. }\end{array}$ \\
\hline
\end{tabular}




\begin{tabular}{|c|c|}
\hline & - Reactivation stage: Communication and coordination. \\
\hline $\begin{array}{l}\text { Argente-Linares et al. } \\
\text { (2013a) }\end{array}$ & $\begin{array}{l}\text { - Foreign partner majority ownership, management by a local CEO, effort made by each party to adapt to the management } \\
\text { style of the other positively influence IJV performance in Morocco. }\end{array}$ \\
\hline $\begin{array}{l}\text { Argente-Linares et al. } \\
(2013 b)\end{array}$ & $\begin{array}{l}\text { - IJV partners satisfaction are influenced by the existence of external directors, board of directors with a significant level of } \\
\text { ownership in the IJV, the existence of an audit committee, and the low frequency of Board meetings. }\end{array}$ \\
\hline $\mathrm{Dad}$ & $\begin{array}{l}\text { - JV ownership positively affects the performance of foreign subsidiaries in Ghana, independent of the measure of } \\
\text { performance. } \\
\text { - Market-seeking IJVs were the ten best investments in terms of performance (measured by mean of performance) and when } \\
\text { the perceived cultural distance from Ghana was high. }\end{array}$ \\
\hline Kivrak et al. & $\begin{array}{l}\text { - Effective communication and language, personal relationships, motivation, and organizational culture improved } \\
\text { knowledge sharing in Turkish-Libyan IJV. }\end{array}$ \\
\hline $\begin{array}{l}\text { Foster-Mcgre } \\
(2015)\end{array}$ & $\begin{array}{l}\text { - IJVs and foreign-owned firms tended to perform better than domestically owned firms, especially IJVs in manufacturing } \\
\text { firms. }\end{array}$ \\
\hline $\begin{array}{l}\text { Gómez-Miranda et al. } \\
\text { (2015) }\end{array}$ & $\begin{array}{l}\text { - Involvement of IJV staff in management, the degree of decision-making centralization, and a management focus on } \\
\text { results rather than procedures influenced the efficiency and effectiveness of the IJVs. }\end{array}$ \\
\hline Hearn (2015) & $\begin{array}{l}\text { - Social and political legitimacy challenges dominate the external role of boards. } \\
\text { - Growing proportions of Board of Directors are drawn from commercial and governmental social elites in IJVs. }\end{array}$ \\
\hline $\begin{array}{l}\text { Ado, Su \& Wanjiru R. } \\
\text { (2017) }\end{array}$ & $\begin{array}{l}\text { - African partners enthusiastically take advantage of multiple cultural and social capital-related factors to support learning. } \\
\text { - Africans use structural capital such as informal channels to manage cultural differences and build trust to gain knowledge. } \\
\text { - Africans use relational capital, cognitive capital, and experienced learners to facilitate learning and knowledge transfer. }\end{array}$ \\
\hline Dadzie et al. & $\begin{array}{l}\text { - Cultural distance and country risk influence the choice of joint ventures in Ghana. } \\
\text { - Efficiency-seeking and resource-seeking FDIs lead to the choice of the joint ventures in Ghana. }\end{array}$ \\
\hline $\begin{array}{l}\text { Odediran \& Windapo } \\
\text { (2017) }\end{array}$ & $\begin{array}{l}\text { ousiness, the threat of terrorism, and political uncertainty in African } \\
\text { nt venture (JV) as entry modes. }\end{array}$ \\
\hline
\end{tabular}




\section{What do we know about IJV research themes in Africa?}

Figure 1 above shows that at least one study has been conducted with regard to each of the IJV themes (except human resources management (HRM), trust and conflict issues in IJVs, which revealed zero publications), with a majority of studies focused on IJV performance and dissolution, motives and entry decisions, and formation and governance. Surprisingly, partner selection and IJV negotiation, trust and conflict, and HRM in IJVs were covered in the fewest number of research publications. A summary of the contributions of these studies is shown in Table 8 above. In the next section, we summarize the specific contributions of these studies.

\subsection{IJV entry decisions and entry motives into Africa}

Our systematic review revealed four studies on the reasons that foreign firms enter Africa through IJVs (Boateng \& Glaister, 2003; Dadzie, Owusu, Amoako, \& Aklamanu, 2017; Luiz \& Charalambous, 2009; Odediran \& Windapo, 2017). In addition, five studies explored the strategic motives of IJVs in Africa (Acquaah, 2009; Banai \& Akande, 2005; Bartels, Johnson, \& Ahmed, 2002; Boateng \& Glaister, 2003; Luiz \& Charalambous, 2009). These five studies focused on not only entry modes and overall strategic motives but also on the effect of specific factors such as culture, market environment, and institutions.

The above studies found that IJVs were a preferred mode for foreign companies to enter African markets in order to overcome possible difficulties (Boateng \& Glaister, 2003; Dadzie et al., 2017). Foreign companies used IJVs for collaborating with local companies to gain local knowledge and resources and for navigating perceived cultural and institutional obstacles (Dadzie et al., 2017; Luiz \& Charalambous, 2009; Odediran \& Windapo, 2017). South African and non-African IJV partners 
entered African markets mainly for market access and resources (Bartels et al., 2002). In comparing the IJV to the wholly owned subsidiary, the IJV was chosen for its relative efficiency (Boateng \& Glaister, 2003; Dadzie et al., 2017). However, there were some important differences in the strategic emphases of the foreign IJV partners in primary industries (agriculture and mining), where resource-seeking was very important, compared to those in manufacturing and services (e.g., information technology), where efficiency-seeking was paramount (Boateng \& Glaister, 2003; Dadzie et al., 2017). Foreign IJV partners entering Africa tended to contribute the technology and the majority of the top management (Bartels et al., 2002). This was true also of South African firms entering other African markets (Luiz \& Charalambous, 2009; Odediran \& Windapo, 2017). There was also a difference between the market strategies of IJVs with partners from developed countries and those from emerging economies. Those from developed economies tended to pursue a differentiation strategy, while those from emerging markets pursued cost leadership strategies with standardized products and a broad customer base (Acquaah, 2009). While these studies provide scientific contribution as to why foreign firms seek IJVs in Africa, they are, however, limited to a small number of countries, mainly Ghana and South Africa.

\subsection{Performance and dissolution of IJVs in Africa}

Performance and dissolution were the themes examined by the highest number of studies. IJVs with foreign companies were found to perform better than domestically owned firms in 19 subSaharan African countries (Foster-McGregor et al., 2015). The most important factor for positive performance was good collaboration between partners (Famakin et al., 2012). This collaboration was based on each partner's contributing its capabilities-i.e., the foreign companies' contributions of technological, managerial, and financial resources and the local company's contribution of 
cultural, institutional, and relationship management competencies (Bartels et al., 2002; Dadzie et al., 2014). One interesting finding was that IJVs with private companies performed better than those with public companies (Boateng \& Glaister, 2002). In addition, IJVs with partners from developed countries performed better when they used a differentiation strategy. This is in contrast to IJVs from emerging markets, which did better when they used a cost leadership strategy (Acquaah, 2009). In addition, market-seeking IJVs performed better against a backdrop of high perceived cultural distance (Dadzie et al., 2014). The involvement of locals in top management positively influenced the level of profitability when the foreign IJV partners had little experience in the African market (Argente-Linares et al., 2013a).

Overall, while the studies on performance were conducted in more countries than the studies on entry decisions and motives, most of the studies were done in Ghana. Studies were done in Nigeria, Morocco, Namibia, and 19 other African countries, but the number was still small.

\subsection{Knowledge transfer and learning in IJVs in Africa}

While there are only three studies on this theme, some interesting findings were made. Technology transfers from foreign technologically more advanced partners succeed if the local partners have the basic capabilities in the industry (Carrillo, 1996). Effective communication, the development of informal and personal relationships, and informal team-building activities outside working hours helped to develop trust, to bridge communication gaps, and to facilitate the knowledge transfers (Carrillo, 1996; Kivrak et al., 2014). In one study of a Chinese JV partner and the African JV staff, the African partners actively took advantage of multiple cultural and social capital-related factors to support learning even though the Chinese parent company had made it challenging for them to acquire knowledge through the formal protocols (Ado et al., 2017). In other words, the Africans 
used structural capital (i.e., informal channels and ties and clandestine mechanisms) to bridge the cultural differences and to build trust to facilitate knowledge sharing. They also used relational capital (i.e., informal communication, informal networking, and informal trust), cognitive capital (i.e., informal culture sharing, and informal goal sharing), and experienced learners (i.e., individuals knowledgeable about Chinese sociology and business culture) to facilitate learning and to gain knowledge.

\subsection{IJV formation, ownership and control, and partner selection in Africa}

Six studies investigated IJV formation, financing, ownership, and control. One study investigated partner selection. There were some interesting findings. The decision about the type of capital invested in the IJV was based on the tax and repatriation laws of the host country. In one study, foreign partners preferred debt as a form of financing to reduce their tax burden and to facilitate the repatriation of the profits (Boateng, 2004). Another study found a greater likelihood of a larger initial investment of capital in the case of IJVs with public companies than IJVs with private companies (Boateng et al., 2002). In a majority of cases, foreign CEOs and top officials were seen as a better management resource (Bartels et al., 2002); however, one case revealed that local CEOs had a positive effect on the performance of the IJV (Argente-Linares et al., 2013). In addition, Banai and Akande (2005) found a difference in the case of South Africa, where the local managers preferred to hold a majority of the high managerial positions (compared to the foreign JV partners).

Only one study investigated partner selection in Africa. It found that resource complementarities, prior alliance experience and reputation, similarity in status of the firms (complementary capabilities and compatible operating systems and practices) were essential criteria used in 
selecting an alliance partner. The study also showed that in the presence of trust in the alliance partner, the need for contractual clauses in the formation of the alliance was eliminated. These strategies are similar to those for general partner selection reported in previous studies in other parts of the world.

\section{Contextualization of the Research Findings}

Most of the studies on the reasons firms choose to enter the African market through IJV suggest the importance of institutions in the firms' strategic choices. However, these studies have not explored institutional theories specifically but, rather, have focused on literature syntheses and measures of institution-based constructs used in mainstream IB studies. For example, they suggest that firms prefer JVs because of the institutional challenges, such as terrorism and political risks, (Odediran \& Windapo, 2017), regulatory restrictions (Boateng \& Glaister, 2003), government suasion (Bartels et al., 2002; Boateng \& Glaister, 2003), country risks, and cultural distance (Dadzie et al., 2017), in these countries. Terrorism and political risks are constructs in institutional theory. They relate to failures in formal institutions (see Oguji \& Owusu, 2017a). Regulatory restrictions, country risks, and cultural distance are constructs related to formal and informal institutional distance (see Arslan \& Larimo, 2011; Contractor, Lahiri, Elango, \& Kundu, 2014; Oguji \& Owusu, 2017a). The reviewed research suggests that institutions are a predominant factor affecting entry into African markets through IJVs because foreign companies need the knowledge of their local partners on culture, relationships and networks, navigating institutional barriers, or conforming to institutional pressures (e.g., government suasion) to enhance their ability to succeed (Luiz \& Charalambous, 2009). 
We therefore suggest a deeper analysis of the relationship between institutions and IJV entries in Africa. Specifically, we see a close link between institutions and IJV strategic choices in Africa, but more studies are needed to understand the extent of the effect of the institutional environment on IJVs. For example, it has often been suggested that the greater the institutional difference, the higher the likelihood of acquisitions in the emerging market context of India and China (Contractor et al., 2014). In the context of Africa, recent studies of entries between 2008 and 2013 show that MNEs are more likely to enter African countries with rapidly improving formal institutions through greenfield investments, especially if they have prior investment experience in Africa or if they have local government connections (Chen, Cui, Li, \& Rolfe, 2017). Although the empirical findings are not conclusive, the findings from this literature review indicate that, in the context of Africa, challenges in host country institutions give rise to IJVs. In contrast, a recent case study of three acquisitions in Kenya, Morocco, and South Africa in 2013, 2010, and 2007, respectively, suggested that the state of institutions in Africa led to the preference for staged and full acquisitions (Oguji \& Owusu, 2017a). A fundamental question is "is the African context a ground to test the limits of institutional theory? Is it the boundary conditions where institutions and business strategies coexist in all strategic options? That is, if all business strategies are affected positively by institutional elements, is the institutional environment a precursor to a firm's strategy? This is an important research question as researchers delve more deeply into the African context.

In the context of Africa, the performance of IJVs is seen as an integration of strategy path dependency and a firm's resources and capabilities (Acquaah, 2009; Foster-Mcgregor et al., 2015). Some authors argued that the determinants of IJV performance in the mainstream literature, such as partner capabilities and the congruity of motives and goals, apply to the context of Africa (Boateng \& Glaister, 2002; Famakin et al., 2012). Others argued for the significant role of local 
partners in enhancing the performance of IJVs, especially market-seeking IJVs (Dadzie et al., 2014) and the service industries (Luiz \& Charalambous, 2009), even in challenging institutional environments (Bartels et al. 2002). While the above-mentioned studies focused on the strategic paths of the IJVs, authors such as Argente-Linares et al. (2013a, 2013b) and Gómez-Miranda et al. (2015) extended the study of performance to include the role and nationality of the CEO and ownership by the staff and the board of directors in IJV performance in Africa. They argued for selecting a CEO who hails from the host country or an experienced foreign national who is knowledgeable about the host country's business environment.

Within the African context, the measures adopted for IJV performance included mostly perceptions (e.g., Acquaah, 2009; Argente-Linares et al., 2013a, 2013b; Bartels et al., 2002; Boateng \& Glaister, 2002; Dadzie et al., 2014; Gómez-Miranda et al., 2015). Only a few studies used financialand accounting-based measures (e.g., Foster-Mcgregor et al., 2015), which are often considered objective. Although IJV performance has been studied extensively, opinions on measurement vary, and a mix of objective (e.g., profit and market share) and subjective measures (e.g., managerial satisfaction) is often employed. Despite the ongoing debate over measures of IJV performance, researchers have suggested and have called for motive-based performance measures (Verbeke, $\mathrm{Li}$, \& Goerzen, 2009).

We do not suggest that perceived measures are inappropriate; however, we argue for the constructs to be motive or goal-oriented. Because the formation of IJVs is driven by various goals, the measurement of their performance should be based on the achievement of the a priori goals rather than general performance measures or measures not aligned with the initial goals. For example, irrespective of the institutional challenges in Africa, we found compelling evidence related to the 
achieved goals in market-seeking IJVs (Dadzie et al., 2014) and efficiency and cost leadership strategies (Acquaah, 2009). Profitability may not be the sole motivation for entering into IJVs. Some foreign parent firms may conform to the institutional pressure of entering Africa through IJVs as a springboard strategy for entering the market and gaining market knowledge in the short term while having a long-term strategy of future greenfield investments or full or majority ownership of the IJV over time. This has been shown in studies of the conversion of IJVs into wholly owned subsidiaries (Puck, Holtbrugge, \& Mohr, 2009). Consequently, we recommend goalbased performance measures in future IJV studies in Africa. We also recommend an examination of how these goals were achieved, how they ensured local partners' commitments, and how the local partners contributed to them.

While we cannot generalize about the knowledge transfer themes in the IJVs in Africa from just three studies, there are issues worth understanding within the African context. First, informal networks are crucial for knowledge transfers and serve as a mechanism for mitigating the negative effects of cultural differences and hierarchical organization forms, thereby facilitating learning and knowledge acquisition in IJVs. While Ado et al. (2017) highlighted the use of informal mechanisms, specifically within the context of China-Africa JVs, rather than formal protocols and procedures, as in Carrillo (1996), future studies will need to determine whether this is a function of foreign parent origin. Moreover, the use of knowledge transfer mechanisms by foreign partners, the success of these mechanisms, and their overall relationship to the performance and survival of JVs will be important for future studies. Studies have shown that the knowledge transfer process is context specific and varies because of differences in national cultures (Kivrak et al. 2014), industry structures, and educational systems (Meyer, 2007). For this reason, we assume that the ways in which African firms acquire knowledge from parent firms in IJVs could be somewhat different 
from the transfer mechanisms used in developed economies. Future studies should explore knowledge transfer mechanisms and the role of institutional and educational differences in foreign firms' development of knowledge transfer mechanisms.

With regard to IJV control mechanisms, we argue that further research is required. Studies should explore other control mechanisms used by foreign partners in Africa. Future studies could also investigate whether the appointment of a CEO by either the local partner or the foreign partner has an effect on the performance of the IJV. These studies could examine the effect of the control mechanisms related to the nationality of the CEO on the performance of IJVs.

\subsection{Theoretical Framework}

The reviewed studies are context-specific, and they are focused on Africa. Context-specific studies aim to contribute to broader themes through the analysis of a specific context - in this case, the African context (Kolk \& Rivera-Santos, 2016). The justification for the African context was the many market reforms and institutional developments that have taken place over several decades, leading to growth in FDIs in this region. Interest in Africa has been increasing; thus, the limited amount of research knowledge on IJV themes in Africa necessitated the focus of these studies. While the findings are not exhaustive or conclusive, we believe that the authors have shown the importance of context-specific studies, especially studies on Africa.

Based on the analysis of the 22 articles reviewed, the authors of this paper have developed a conceptual framework and have made four propositions regarding IJV themes in Africa. Our framework and propositions are focused on themes with a significant number of contributions (see 
Figure 4). The framework shows that in the IJV studies in Africa, the motives for IJVs, IJV formation, as well as institutional-based factors, IJV commitment and trust, and knowledge transfer issues influenced the IJV entry decisions, and this in turn influenced the performance of the IJVs in Africa.

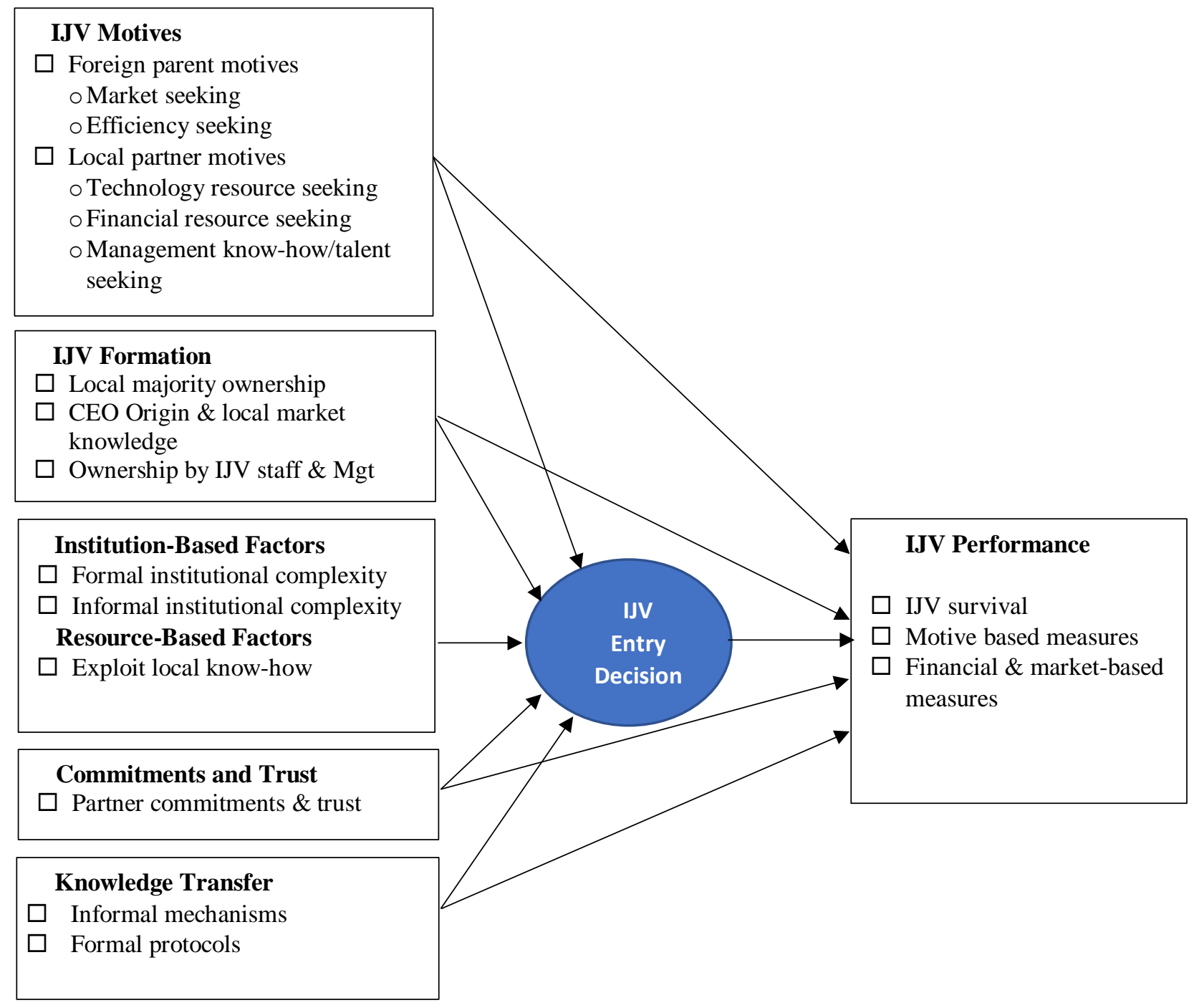

Figure 4: Conceptual Framework: IJV Literature Review \& Themes in the African Context 


\subsection{Propositions}

With regard to IJV entry decisions, we saw a more significant role for the host countries' formal

and informal institutions in the IJV entry decisions. We argue that while market reforms have resulted in remarkable progress in most African countries compared to the previous decades, regulatory restrictions in specific industries and legislation still hinder the full ownership of foreign investments (see, e.g. Kalinova, Palerm, \& Thomsen, 2010 for country and sector reviews; UNCTAD, 2006). Furthermore, because political risks in Africa are lower today than they were decades ago, we will continue to see an increase in the ability of MNEs to co-exist with the institutional pace of the African countries. We expect that these MNEs will focus their efforts on developing competencies in managing institutional complexities in these markets as costs continue to rise in China and South East Asia and the impetus for establishing production facilities in Africa increases. We will continue to see efforts by African governments to promote IJVs and to attract investors through FDI promotion strategies and new legislation. Thus, we expect an increase in the use of IJVs, especially for entering key resource industries in Africa. In addition, foreign firms will use such ventures as vehicles for mitigating institutional complexities as African economies undergo economic and institutional changes. Thus, we propose the following:

Proposition 1: Formal and informal institutional complexities in host African nations are positively related to an increase in the use of IJV entry mode (or removal of formal and informal institutional complexities in host African nations will decrease the use of IJV entry mode).

Strategic assets are concentrated in the developed economies (Makino, Lau, \& Yeh, 2002). For this reason, we will continue to see IJVs with market-seeking and efficiency-seeking motives in Africa (Dadzie et al., 2017). While foreign partners will continue to pursue these motives, local partners 
will continue their efforts to acquire technological skills and management expertise from foreign partners. Furthermore, we expect that a critical challenge for both foreign and local partners will be the achievement of their strategic motives for entering the IJVs. For the foreign partners, the ability to eventually acquire the JVs, the commitment and trust of the local partners, the survival of the JVs, and the achievement of their strategic motives will be of vital concern. In contrast, local partners will aim for the acquisition of technology and management expertise, but they will also benefit from high levels of commitment and trust. Thus, we expect a relationship between motives and partner commitments in the performance of IJVs in Africa. Therefore, we propose the following:

Proposition 2: IJV performance in Africa is positively related to the fit between the strategic objectives of the partners and their commitment and trust (or a loss of fit between strategic objectives of the partners and their commitment and trust will have a negative effect on IJV performance in Africa).

Knowledge transfer mechanisms seem to be somewhat different within the African context compared to the developed market context. Ado et al. (2017) highlighted the importance of informal mechanisms in Africa for the acquisition of knowledge from foreign partners. Thus, we expect the mechanisms of knowledge transfer to be different in Africa because of the importance of informal mechanisms. The ability to understand and to manage informal mechanisms will affect the success of knowledge transfers. We therefore propose the following:

Proposition 3: Informal mechanisms of knowledge transfer in Africa are positively related to IJV performance (or loss of informal mechanisms of knowledge transfer in Africa will have a negative effect on IJV performance). 
A significant body of IJV literature has shown that dominant managerial control exercised by foreign parents has a positive influence on the performance of an IJV (e.g., Ding 1997). The role of expatriate managers in steering the IJV through the liabilities of newness and foreignness (Dutta \& Beamish, 2013; Zaheer \& Mosakowski, 1997) and facilitating the deployment of the relevant expertise and capabilities to create the stability needed for the success of the IJV has been discussed in the IJV literature. In the context of Africa, empirical evidence suggests that the appointment of a CEO who hails from the host country of the IJV or a CEO who understands the local market has a positive influence on the performance of the IJV (Argente-Linares et al., 2013a, 2013b; GómezMiranda et al., 2015).

While Choi and Beamish (2004) did not find any significant performance differences in local partner-dominant management, we saw a significant positive role played by local partners in the performance of IJVs in Africa (Bartels et al., 2002; Boateng \& Glaister, 2003; Dadzie et al., 2014; Hearn, 2015; Luiz \& Charalambous, 2009). As a result, we expect local managerial control to be positively linked to the success of IJVs in Africa. Based on this, we propose that:

Proposition 4: Local managerial control of IJVs in Africa is positively related to the performance of IJVs.

\section{Conclusions}

There were no studies on HRM or the role of trust and its creation and development in IJVs within the African context. Moreover, there was only one study on IJV partner selection among our reviewed papers. We call for future research to address these gaps. In summary, we see less attention of local researchers to IJV themes. We believe it is critical that local researchers increase 
their contributions to the advancement of research in these areas. Further, foreign partners could form research partnerships and collaborations with local universities in Africa to increase the amount and the quality of research conducted on the African context. There are avenues for more theoretical studies on IJV research themes. We encourage researchers to integrate relationship management and network theories, social exchange theory, the institutional-based view of international business, national and organizational culture theories, and the theory of corruption in future studies. These theories will lead to more contextual findings in IJV research themes in Africa. While these theories have not been rigorously applied in the African context, the empirical research reviewed in this paper shows that they are potentially valuable in improving our understanding of African business, thus enriching theory and management practices.

The business network theory postulates that successful internationalization centers on the firm's ability to embed itself in multiple business networks in host nations (Andersson, Forsgren, \& Holm, 2007; Degbey \& Pelto, 2013, 2015; Forsgren, 2013). Because the focus of this theory is the business relationships surrounding each focal actor or firm, the integration of network theories into the discussion of IJV core themes in Africa can provide more theoretical insight into some of the underexplored core themes in IJV research. For example, our literature review of the IJV research themes in Africa clearly demonstrates a lack of focus on core themes, such as partner selection criteria, trust and conflict. At the heart of the business network theory is the assumption that business-to-business exchange partners are engaged in relatively stable and long-lasting relationships that they deem important for their business (Degbey, 2015; Håkansson, 1982). Therefore, insights from network theory are important because they form the foundation for firms' relational competence development (see, Forsgren, 2013). In addition, they could help prospective IJV parent firms or managers to gain a better understanding of the competent selection of IJV 
partners to ensure stable and long-lasting IJVs, especially within the African context. Thus, we invite scholars to employ the business network theory to explore some of the aforementioned underexplored core themes in IJV research within the Africa context.

Social exchange theory is another valuable lens for enhancing our understanding of IJV activities within the African continent, especially with respect to the underexplored IJV core themes. Though related to a core notion of the business network theory (i.e., relationships), social exchange theory is concerned more with interpersonal connections-social exchange relationships. Specifically, social exchange theory focuses on the quality of social interactions in a person's network of relationships (Blau, 1964; Brandes, Dharwadkar \& Wheatley, 2004;). While multiple intellectual perspectives of social exchange theory have emerged, scholars agree that social exchange encompasses a series of interactions that produce obligations and that such interactions are often interdependent and are contingent upon the actions of another person (Emerson, 1976). Therefore, the presence of such high-quality social interactions demands certain rules and norms of exchange. According to Emerson (1976, p. 351) such rules and norms of exchange form a "normative definition of the situation that forms among or is adopted by the participants in an exchange relation."

Reciprocity and negotiated rules have attracted much attention in the social exchange theory literature although other exchange rules are viable (e.g., Cropanzano \& Mitchell, 2005), and are equally important concepts within the domain of IJV research (e.g., Parkhe, 1993). In this article, our literature review on IJV research themes in Africa shows there was no publication with a focus on HRM. Thus, we believe that social exchange theory can make significant contributions to the IJV literature in this regard because it is focused on employee workplace relationships (e.g., 
Settoon, Bennett \& Liden, 1996; Shore \& Coyle-Shapiro, 2003). Other scholars have noted that social exchange theory ranks among the most influential conceptual paradigms for understanding workplace behavior (Cropanzano \& Mitchell, 2005). It can certainly enhance our understanding of the HRM characteristics that engender reciprocity and influence performance within IJVs within the African context. For example, Brandes et al. (2004) discussed two important levels of social exchanges: local and global social exchanges within organizations. These could be employed to improve our understanding of local and foreign employee workplace behavior in IJVs and the consequences (e.g., role behaviors, extra-role behaviors, and employee involvement behaviors) for work outcomes. Another area in which social exchange theory can facilitate the development of more insights is knowledge transfer and learning in IJVs in Africa - an underexplored theme. For example, scholars have highlighted knowledge as a socially created activity (e.g., Berger \& Luckmann, 1996; Cohen \& Prusak, 2001) that happens through socialization, immersion in a culture, and collective teaching (e.g., Junni \& Sarala, 2012; Zander \& Zander, 2010). This, therefore, highlights the vital role of social exchange research in contributing to our improved understanding of knowledge transfer and sharing (see Aklamanu, Degbey, \& Tarba, 2016), as well as learning.

While recent studies have explained the role of institutions in IJVs, one aspect of formal institutions that has gained a great deal of attention in the literature and has been argued to be very relevant because of its effect on the economy is corruption. The theory of corruption suggests that corruption is an economic externality that raises the cost of doing business in general (e.g., Cuervo-Cazurra, 2016; DiRienzo, Das, Cort, \& Burbridge, 2007). Studies have found that high levels of corruption increase the likelihood of IJVs (Demirbag, Glaister, \& Tatoglu 2007; Driffield, Mickiewicz, Pal, \& Temouri 2010; Sartor \& Beamish, 2018; Smarzynska \& Wei, 2002; Uhlenbruck, Rodriguez, 
Doh, \& Eden 2006) in order to deal with local corruption. High levels of corruption are prevalent in most African countries (Transparency International, 2016). As IJVs have been shown to be one of the preferable organizational structures for entering these countries (Boateng, 2004; Dadzie et al., 2014), researchers and managers should be concerned about the process of selecting appropriate partners for IJVs. Extant studies have shown the role of the institutional context in determining partner selection decisions and strategies (Brouthers \& Brouthers, 2001; Delios \& Henisz, 2003). Geringer (1991) developed a framework for partner selection consisting of partner-related (e.g., character and partnering intent) and task-related (e.g. operational skills and resources) criteria. This is the dominant framework, and it has been used extensively in research on partner selection. For example, Roy and Oliver (2009) showed that managers' perceptions about the host country's adherence to the rule of law influence appropriation and coordination cost concerns. This in turn positively influences partner-related selection criteria in IJVs. In the African context, where corruption is prevalent, we expect a high cost for doing business (Kimuyu, 2007): costly coordination of inter-partner activities and inadequate compensation for firms' proprietary technology. For this reason, future studies should look at the partner-related criteria (e.g., trustworthiness, transparency) used by companies. In addition, attention should be paid to the management of appropriation and coordination costs. Corruption affects not only partner selection criteria but also the management of the IJVs. Because of the limited number of studies on HRM, trust, and knowledge transfer themes in IJVs, future studies should explore the effects of the perceptions of corruption in African countries on foreign partners' strategies for managing coordination and appropriation costs, transferring proprietary knowledge, hiring, and building trust with local partners. An additional area that can contribute to improving our understanding of HRM issues in African IJVs is the regulatory aspect of local managerial control. Recent studies have documented the presence of formal institutional constraints, such as restrictive laws on M\&As 
(e.g., Oguji \& Owusu, 2017a) and local content legislation (e.g., Vaaland et al., 2012). Similar studies are needed to enhance our understanding of the recruitment and staffing policies that may enjoin foreign IJV partners to hire more than $50 \%$ of the top managers from the host country, and the implications of such policies.

Organizational culture has a strong effect on the management of and the procedures in organizations (Hofstede, 1991; House et al., 2002;). Organizational culture is said to emanate from largely national cultural characteristics. Studies have delineated the cultural dimensions or traits that tend to permeate societies and to differentiate them (Hofstede, 1991; House et al., 2002). While different dimensions and constructs are presented in different frameworks (Earley, 2006; Jarvidan, 2006; Steenkamp, 2001; Magnusson et al., 2008), the relevance of national and, thus, organizational cultural dimensions is generally accepted despite criticisms of the above frameworks (Venaik \& Brewer, 2013). The role of organizational culture has been studied in IJVs (Gómez-Miranda et al., 2015; Kivrak et al., 2014) and related international business modes like acquisitions (Bjorkman, Stahl, \& Vaara, 2007; Zander \& Zander, 2010).

Cultural difference between partners in countries has been conceptualized as cultural distance, and the size of this distance has been found to affect the performance of JVs and acquisitions because of the need for the integration of the foreign and local partners (Malhorta \& Sivakumar, 2011; Morschetta, Schramm-Kleinb, \& Swobodac, 2010; Quer, Claver, \& Rienda, 2007). Thus, the cultural distance between the African partner and the foreign partner is likely to be high (Darley, Luethge, \& Blankson, 2013). This creates challenges for the development of trust, for knowledge transfer, and for HRM. Partner selection becomes a critical issue for the partners to get it right and stay together "'til death do them part." In some studies, institutional cultural distance is classified 
under informal institutions (Peng et al., 2008; Contractor et al., 2014), and there is limited research on this topic within the context of Africa (Hearn, 2015; Kimuyu, 2007; Luiz \& Charalambous, 2009; Oguji \& Owusu, 2017a). We call for more research to explore organizational culture theories on this important aspect of IJV. We also suggest that future studies focus more on the moderating effect of national culture on the performance of IJVs in Africa. Because of the complexity, uncertainty, and ambiguity of the African context (Chironga, Leke, Lund, \& Van Wamelen, 2011; Mbaku, 2004), there is need for dynamic interactions between national and organizational cultures to enhance organizational effectiveness (Zoogah, Peng, \& Woldu, 2015). Ugwuegbu (2001) indicated that productivity can be affected when ethnic and national cultures interact with organizational cultures. The cultures in Africa are distinct from those of the West; thus, future studies on IJVs must pay attention to this distinctiveness to improve our understanding of IJVs and international strategic alliances in Africa (see, e.g. Gomes, Cohen, \& Mellahi, 2011).

\section{References}

Abramo, G., Cicero, T., \& D'Angelo, C. A. (2014). Are the authors of highly cited articles also the most productive ones? Journal of Informetrics, 8(1), 89-97.

Acquaah, M. (2009). International joint venture partner origin, strategic choice, and performance: A comparative analysis in an emerging economy in Africa. Journal of International Management, $15,46-60$.

Ado, A., Su, Z., \& Wanjiru, R. (2017). Learning and knowledge transfer in Africa-China JVs: Interplay between informalities, culture, and social capital. Journal of International Management, 23, 166179.

Famakin, I. O. Aje, I.O., \& Ogunsemi, D. R. (2012) Assessment of success factors for joint venture construction projects in Nigeria, Journal of Financial Management of Property and Construction, 17(2), 153-165.

Akande, W. A., Adetoun, B. E., Tserere, M. M., Adewuyi, M. F., \& Akande E. T. (2010). Should we put locals in charge? Managing relationships within prospective US-South African joint ventures.

Journal of Business Economics and Management, 11(4), 550-575. 
Akande, W. A., \& Banai, M. B. (2009). Your next boss is American: Attitudes of South African managers towards prospective US-South African joint ventures. South African Journal of Business Management, 40(2), 1-13.

Aklamanu, A., Degbey, W. Y. \& Tarba, S. Y. (2016). The role of HRM and social capital configuration for knowledge sharing in post-M\&A integration: A framework for future empirical investigation. The International Journal of Human Resource Management, 27(22), 2790-2822

Andersson, U., Forsgren, M. \& Holm U. (2007). Balancing subsidiary influence in the federative MNC: A business network view. Journal of International Business Studies, 38(5), 802-818.

Argente-Linares, E., López-Pérez, M. V., \& Rodríguez-Ariza, L. (2013a). Organizational structure and success of international joint ventures in emerging economies. The case of Spanish-Moroccan SMEs. Review of Managerial Science, 7(4), 499-512.

Argente-Linares, E. López-Pérez, M. V., \& Rodríguez-Ariza, L. (2013b). Relation between business satisfaction and board dimensions in joint ventures between Spanish and Moroccan SMEs. South African Journal of Business Management, 44(3), 31-40.

Ashley, C. \& Jones, B. (2001). Joint ventures between communities and tourism investors: Experience in southern Africa. The International Journal of Tourism Research, 3(5), 407-423.

Banai, M., \& Akande D. (2005). South African managers' perceptions of prospective South African-US Joint Ventures. Journal of African Business, 6(1-2), 7-31.

Bartels, F. L., Johnson, J. P., \& Ahmed, Z. U. (2002). International equity joint ventures in Ghana and Cote D'Ivoire. Journal of African Business, 3(3), 5-30.

Bartels, F. L., Napolitano, F., \& Tissi, N. (2014). FDI in Sub-Saharan Africa: A longitudinal perspective on location-specific factors (2003-2010). International Business Review, 23, 516-529.

Beamish, P., \& Berdrow, I. (2003). Learning from IJVs: The unintended outcome. Long Range Planning, $36(3), 285-303$.

Berger, P. L., \& Luckmann, T. (1996). The social construction of reality: A treatise in the sociology of knowledge. New York: Anchor Books.

Boateng, A. (2004). Determinants of capital structure. International Journal of Social Economics, 31(1/2), $56-66$.

Boateng, A., \& Glaister, K. W. (2002). Performance of international joint ventures: Evidence for West Africa. International Business Review, 11, 523-541.

Boateng, A., \& Glaister, K. W. (2003). Strategic motives for international joint venture formation in Ghana. Management International Review, 43(2), 107-128. 
Boateng, A., Akamavi, R., \& Henderson, R. (2002). International joint ventures in West Africa: Sources of funding and barriers to finance. International Journal of Business Studies, 10(1), 59-72.

Bowea, M., Golesorkhib, S., \& Yamina, M. (2014). Explaining equity shares in international joint ventures: Combining the influence of asset characteristics, culture, and institutional differences. Research in International Business and Finance, 31, 212-233.

Bozic, B. (2017). Consumer trust repair: A critical literature review. European Management Journal, 35(4), 538-547.

Brass, D. J., Galaskiewicz, J., Greve, H. R. \& Tsai. W. (2004). Taking stock of networks and organizations: A multilevel perspective. Academy of Management Journal, 47(6), 795-817.

Brandes, P., Dharwadkar, R., \& Wheatley, K. (2004). Social exchanges within organizations and work outcomes: The importance of local and global relationships. Group \& Organization Management, 29(3), 276-301.

Brouthers, K. D., \& Brouthers, L. E. (2001). Explaining the national cultural distance paradox. Journal of International Business Studies, 32(1), 177-189

Callahan, J. L. (2014). Writing literature reviews: A reprise and update. Human Resource Development Review, 13(3), 271-275.

Caroline, A. \& Brian, J. (2001). Joint ventures between communities and tourism investors: Experience in southern Africa. The International Journal of Tourism Research, 3(5) 407-423.

Carrillo, P. (1996). Technology transfer on joint venture projects in developing countries. Construction Management and Economics, 14(1), 45-54.

Chen, S.-F. (2008). The motives for international acquisitions: Capability procurements, strategic considerations, and the role of ownership structures. Journal of International Business Studies, 39(3), 454-471.

Chen, R., Cui, L., Li, S., \& Rolfe, R. (2017). Acquisition or Greenfield entry into Africa? Responding to institutional dynamics in an emerging continent. Global Strategy Journal, 7, 212-230.

Chironga, M., Leke, A., Lund, S., \& Van Wamelen, A. (2011). Cracking the next growth market: Africa. Harvard Business Review, 89, 117-122.

Choi, C.-B., \& Beamish, P. W. (2004). Split management control and international joint venture performance. Journal of International Business Studies, 35(3), 201-215.

Cohen, D., \& Prusak, L. (2001). In good company: How social capital makes organizations work. Boston, MA: Harvard Business School Press. 
Contractor, F. J., Lahiri S., Elango B., \& Kundu, S.K (2014). Institutional, cultural and industry related determinants of ownership choices in emerging market FDI acquisitions. International Business Review, 23(5), 931-941

Creswell, J. W. (2013). Research design: Qualitative, quantitative, and mixed methods approaches. Sage publications.

Cropanzano, R. \& Mitchell, M. (2005) Social exchange theory: An interdisciplinary review. Journal of Management, 31(6), 874-900

Cuervo-Cazurra, A. (2016). Corruption in international business. Journal of World Business, 51(1), 35-49

Dadzie, S. A., \& Owusu, R. (2015). Understanding establishment mode choice of foreign manufacturing firms in Ghana. International Journal of Emerging Markets, 10(4), 896-920.

Dadzie, S. A., Owusu, R. A., Amoako, K. A., \& Aklamanu, A. (2017). Do strategic motives affect ownership mode of foreign direct investments (FDIs) in emerging African markets? Evidence from Ghana. Thunderbird International Business Review (Article in Press).

Dadzie, S., Larimo, J., Nguyen, H. L. (2014). Foreign subsidiary performance: Evidence from Ghana. Journal of Transnational Management, 19(2), 165-187.

Darley W. K., Luethge D. J., \& Blankson, C. (2013). Culture and international marketing: A Sub-Saharan African context, Journal of Global Marketing, 26(4), 188-202.

Degbey, W. Y. (2015). Customer retention: A source of value for serial acquirers. Industrial Marketing Management, 46, 11-23.

Degbey, W. Y. \& Ellis, K. M. (2017). Africa-An emerging context for value creation with cross-border mergers and acquisitions. In S. Marinova, J. Larimo \& N. Nummela (Eds.), Value Creations in International Business-Volume 1: An MNC Perspective. London: Palgrave Macmillan.

Degbey, W. Y., \& Pelto, E. (2015). Uncovering different forms of customer network changes in M\&A. Management Research Review, 38(11), 1191-1212.

Degbey, W. Y., \& Pelto E. (2013). Cross-border M\&A as a trigger for network change in the Russian bakery industry. Journal of Business and Industrial Marketing, 28(3), 178-189.

Delios, A., \& Henisz, W. J. (2003). Political hazards, experience, and sequential entry strategies: The international expansion of Japanese firms, 1980-1998. Strategic Management Journal, 24(11), $1153-1164$

Demirbag, M., Glaister, K.W., \& Tatoglu, E. (2007). Institutional and transaction cost influences on MNEs' ownership strategies of their affiliates: Evidence from an emerging market. Journal of World Business, 42(4), 418-434. 
Denyer, D., \& Neely, A. (2004). Introduction to special issue: Innovation and productivity performance in the UK. International Journal of Management Reviews, 5/6(3\&4), 131-135.

DiRienzo, C. E., Das, J., Cort, K. T., \& Burbridge, J. (2007). Corruption and the role of information. Journal of International Business Studies, 38(2), 320-332.

Ding, D. Z. (1997). Control, conflict, and performance: A study of U.S.-Chinese joint ventures. Journal of International Marketing, 5(3), 31-45.

Driffield, N. L., Mickiewicz, T., Pal, S., \& Temouri, Y. (2010). Bridging the gap? Corruption, knowledge and foreign ownership. CEDI working papers Centre for Economic Development \& Institutions (CEDI), Brunel University.

Dutta, D. K., \& Beamish, P. W. (2013). Expatriate managers, product relatedness, and IJV performance: A resource and knowledge-based perspective. Journal of International Management, 19(2), 152162.

Easton, G. (2010). Critical realism in case study research. Industrial Marketing Management, 39, 118128.

Earley, P. C. (2006). Leading cultural research in the future: a matter of paradigms and taste. Journal of International Business Studies, 37(6), 922-931.

Ellis, P. D., \& Zhan, G. (2011). How international are the international business journals? International Business Review, 20(1), 100-112.

Emerson, R. M. (1976). Social exchange theory. Annual Review of Sociology, 2, 335-362.

Forsgren, M. (2013). Theories of the multinational firm: A multidimensional creature in the global economy (2nd ed.). Cheltenham, UK: Edward Elgar Publishing.

Foster-Mcgregor, N., Isaksson, A. B., \& Kaulich, F. C. (2015). Foreign ownership and performance in Sub-Saharan African manufacturing and services. Journal of International Development, 27(7), $1197-1222$.

Gómez-Miranda, M. E., Pérez-López, M. C., Argente-Linares, E., \& Rodríguez-Ariza, L. (2015). The impact of organizational culture on competitiveness, effectiveness, and efficiency in SpanishMoroccan international joint ventures. Personnel Review, 44(3), 364-387.

Geringer, J. M. (1991). Strategic determinants of partner selection criteria in international joint ventures. Journal of International Business Studies, 22(1), 41-62.

Gomes, E., Cohen, M., \& Mellahi, K. (2011). When two African cultures collide: A study of interactions between managers in a strategic alliance between two African organizations. Journal of World Business, 46(1), 5-12.

Hofstede, G. (1991) Culture and organizations: Software of the mind. Londaon: McGraw-Hill. 
House, R. J., Hanges, P. J., Javidan, M., Dorfman, P. W., \& Gupta, V., \& GLOBE Associates. (2004). Leadership, culture and organizations: The globe study of 62 societies. Thousand Oaks, CA: Sage Publications.

Håkansson, H. (1982). International marketing and purchasing of industrial goods. Chichester:John Wiley and Sons.

Healy, M., \& Perry, C. (2000). Comprehensive criteria to judge validity and reliability of qualitative research within the realism paradigm. Qualitative Market Research: An International Journal, $3(3), 118-126$.

Hearn, B. (2015). Institutional influences on board composition of international joint venture firms listing on emerging stock exchanges: Evidence from Africa. Journal of World Business, 50(1), 205-219.

Hennart, J.-F., \& Slangen, A. (2007). Greenfield or acquisition entry: A review of the empirical foreign establishment mode literature. Journal of International Management, 13(4), 403-429.

Jacobides, M. G. (2005). Industry change through vertical disintegration: How and why markets emerged in mortgage banking. Academy of Management Journal, 48(3), 465-498.

Javidan, M., House, R.J., Do rfman, P. W., Hanges, P. J. \& Sully de Luque, M. (2006). Conceptualizing and measuring cultures and their consequences: A comparative review of GLOBE's and Hofstede's approaches. Journal of International Business Studies, 37(6), 897-914.

Junni, P., \& Sarala, R. M. (2012). The role of cultural learning and collective teaching initiatives in M\&A knowledge transfer. European Journal of Cross-Cultural Competence and Management, 2, 275298.

Kalinova, B., Palerm, A. \& Thomsen, S. (2010). OECD's FDI restrictiveness index: 2010 update. (OECD Working Papers on International Investment, 2010/03). Paris: OECD Publishing.

Kolk, A., \& Lenfant, F. (2010). MNC reporting on CSR and conflict in Central Africa. Journal of Business Ethics, 93(2), 241-255.

Kostova, T., \& Hult, G. T. M (2016). Meyer and Peng's 2005 article as a foundation for an expanded and refined international business research agenda: Context, organizations, and theories. Journal of International Business Studies, 47(1), 23-32.

Kimuyu, P. (2007). Corruption, firm growth and export propensity in Kenya. International Journal of Social Economics, 34(3), 197-217

Kivrak, S., Arslan, G., Tuncan, M., \& Birgonul, M. T. (2014). Impact of national culture on knowledge sharing in international construction projects. Canadian Journal of Civil Engineering, 41(7), 642649. 
Luiz, J. M., \& Charalambous, H. (2009). Factors influencing foreign direct investment of South African financial services firms in Sub-Saharan Africa. International Business Review, 18(3), 305-317.

Lu, J.W., Li, W., Wu, A., \& Huang, X. (2017). Political hazards and entry modes of Chinese investments in Africa. Asia Pacific Journal of Management, 28, 1-23.

Mbaku, J. M. (2004). Institutions and development in Africa. Trenton, NJ: Africa World Press.

Mellahi, K., \& Harris, L. C. (2016). Response rates in business and management research: An overview of current practice and suggestions for future direction. British Journal of Management, 27(2) 426437.

Magnusson P., Wilson R. T., Zdravkovic, S., Zhou J. X., \& Westjohn, S. A. (2008). Breaking through the cultural clutter. International Marketing Review, 25(2), 183-201.

Malhorta, S. , \& Sivakumar , K. (2011). Simultaneous determination of optimal cultural distance and market potential in international market entry. International Marketing Review, 28(6), 601-628.

Marabelli, M., \& Newell, S. (2014). Knowing, power and materiality: A critical review and reconceptualization of absorptive capacity. International Journal of Management Reviews, 16(4), 479-499.

Martineau, C., \& Pastoriza D. (2016). International involvement of established SMEs: A systematic review of antecedents, outcomes, and moderators. International Business Review, 25(2), 458-470.

Meyer, K. (2007) Contextualizing organizational learning: Lyles and Salk in the context of their research. Journal of International Business Studies, 38(1), 27-37.

Morschetta, D. , Schramm-Kleinb, H. , Swobodac, B. (2010). Decades of research on market entry modes: What do we really know about external antecedents of entry mode choice? Journal of International Management, 16(1), 60-77.

Ngowi, A. B. (2007). The role of trustworthiness in the formation and governance of construction alliances. Building and Environment Volume, 42(4), 1828-1835.

Odediran, S. J., \& Windapo, A. O. (2017). Mitigating risks in African construction markets through the interactive behavior of resources and capabilities in multinational construction companies and entry decisions. Journal of Management in Engineering, 33(2), 1-14.

Oguji, N, \& Owusu, R. A. (2017a). Acquisition entry strategies in Africa: The role of institutions, targetspecific experience, and host-country capabilities - The case acquisitions of Finnish multinationals in Africa. Thunderbird International Business Review, 59(2), 209-225. 
Oguji, N, \& Owusu, R. A. (2017b). Market entry into Africa: Acquisitions and international joint ventures. Calls for Papers. Thunderbird International Business Review.

Pak, Y. S., \& Park, Y. R (2004). A framework of knowledge transfer in cross-border joint ventures: An empirical test of the Korean context. Management International Review, 44(4), 417-434.

Park, B., Giroud, A., Mirza, H., \& Whitelock, J. (2008). Knowledge acquisition and performance: The role of foreign parents in Korean IJVs. Asian Business \& Management, 7, 11-32.

Parkhe, A. (1993). "Messy" research, methodological predispositions, and theory development in international joint ventures. Academy of Management Review, 18(2), 227-268.

Peng, M. W., Wang, D. Y. L., \& Jiang, Y. (2008). An institution-based view of international business strategy: A focus on emerging economies. Journal of International Business Studies, 39(5), 920936.

Peterson, M. (2016). A culture theory commentary on Meyer and Peng's theoretical probe into Central and Eastern Europe. Journal of International Business Studies, 47(1), 33-43.

Podsakoff, P., MacKenzie, S., Bachrach, D., \& Podsakoff, N. (2005). The influence of management journals in the 1980s and 1990s. Strategic Management Journal, 26, 473-488.

Puck, J. F., Holtbru, D., \& Mohr, A. (2009). Beyond entry mode choice: Explaining the conversion of joint ventures into wholly owned subsidiaries in the People's Republic of China. Journal of International Business Studies, 40(3), 388-404.

Quer, D., Claver, E., \& Rienda, L. (2007). The impact of country risk and cultural distance on entry mode choice: An integrated approach. Cross Cultural Management, 14(1), 74 - 87.

Sartor, M. A., \& Beamish, P. W. (2018). Host market government corruption and the equity-based foreign entry strategies of multinational enterprises Journal of International Business Studies, 49(3), 346370.

Settoon, R. P., Bennett, N., \& Liden, R. C. (1996). Social exchange in organizations: Perceived organizational support, leader-member exchange, and employee reciprocity. Journal of Applied Psychology, 81, 219-227.

Shore, L. M., \& Coyle-Shapiro, J. A. M. (2003). New developments in the employee-organization relationship. Journal of Organizational Behavior, 24(5), 443-450.

Sinkovics, R. R., Penz, E., \& Ghauri, P. N. (2008). Enhancing the trustworthiness of qualitative research in international business. Management International Review, 48, 689-713. 
Smarzynska B. K., \& Wei, S.-J., (2002). Corruption and cross-border investment: Firm-level evidence. (Working Papers Series 494). Ann Arbor: William Davidson Institute at the University of Michigan.

Snyman, S. (2012). Ecotourism joint ventures between the private sector and communities: An updated analysis of the Torra Conservancy and Damaraland Camp partnership, Namibia. Tourism Management Perspectives, 4, 127-135.

Slangen, A., \& Hennart, J .F. (2007). Greenfield vs. acquisition: A review of the empirical foreign establishment mode literature. Journal of International Management, 13(4), 403-429.

Sobh, R., \& Perry, C. (2006). Research design and data analysis in realism research. European Journal of Marketing, 40(11/12), 1194-1209.

Steenkamp, J.-B. E. M. (2001), The role of national culture in international marketing research. International Marketing Review, 18(1), 30-44.

Svensson, G., Tronvoll, B., \& Slatten, T. (2008). "Empirical characteristics" and "geocentricity" in "top" journals of logistics management. The International Journal of Logistics Management, 19(3), 436450 .

Transparency International (2016). Corruption perceptions index. https://www.transparency.org/news/feature/corruption_perceptions_index_2016

UNCTAD. (2006). Measuring restrictions on FDI in services in developing countries and transition economies. Retrieved from http://unctad.org/en/docs/iteiia20061_en.pdf

UNCTAD. (2015). World Investment Report 2015:Value of cross-border M\&A sales, by sector/industry, 1990-2014. http://unctad.org/en/pages/PublicationWebflyer.aspx?publicationid=1245

Ugwuegbu, D. C. E. (2001). The psychology of management in African organizations. Westport, CT: Quorum.

United Nations. (2014) World Economic Situation and Prospects. Retrieved from http://www.un.org/en/development/desa/policy/wesp/wesp_current/2014wesp_country_classification. pdf

Uhlenbruck, K., Rodriguez, P., Doh, J., \& Eden, L. (2006). The impact of corruption on entry strategy, evidence from telecommunication projects in emerging economies. Organization Science, 17(3), $402-414$.

Vaaland1, T. I., Soneye, A. S. O., \& Owusu, R. A. (2012). Local content and struggling suppliers: A network analysis of Nigerian oil and gas industry. African Journal of Business Management 6(15), 5399-5413.

Venaik, S,.l, \& Brewer, P. (2013). Critical issues in the Hofstede and GLOBE national culture models. International Marketing Review, 30(5), 469-482 
Verbeke, A., Li, L., \& Goerzen, A. (2009). Toward more effective research on the multinationalityperformance relationship. Management International Review, 49(2), 149-162.

Welch, C., Piekkari, R., Plakoyiannaki, E., \& Paavilainen-Möntymäki, E. (2011). Theorizing from case studies: Towards a pluralist future for international business research. Journal of International Business Studies, 42(5), 740-762.

World Bank. (2011). World investment and political risk. Washington, DC: Multilateral Investment Guarantee Agency (MIGA).

World Bank. (2012). Doing business 2012: Doing business in a more transparent world [Press releaseSub-Saharan Africa]. Washington, DC: The World Bank Group.

Xie, E., Reddy, K. S., \& Liang, J. (2017). Country-specific determinants of cross-border mergers and acquisitions: A comprehensive review and future research directions. Journal of World Business, 52(3), 127-183.

Zaheer, S., \& Mosakowski, E., (1997). The dynamics of the liability of foreignness: a global study of survival in financial services. Strategic Management Journal, 18(6), 439-463.

Zaheer, A., Gulati, R. \& Nohria N. (2000). Strategic networks. Strategic Management Journal, 21(3), 203-215.

Zander, U., \& Zander, L. (2010). Opening the grey box: Social communities, knowledge and culture in acquisitions. Journal of International Business Studies, 41(1), 27-37.

Zoogah, D. B., Peng, M. W., \& Woldu, H. (2015). Institutions, resources, and organizational effectiveness in Africa. The Academy of Management Perspectives, 29(1), 7-31. 